\title{
Editorial
}

\section{Brand building: The search for principles in advertising}

Here we have a journal dedicated to the study of brand management. A fundamental task of brand management, presumably, is to build strong brands. A strong brand can be defined as a brand with high brand equity resulting in a superior and steady profit flow.

As a first question, we should ask whether brand building is in fact possible. Certainly it is possible in some cases, as Bill Moran's discussion of Marlboro in the previous issue of The Journal of Brand Management indicates. ${ }^{1}$ But perhaps these cases are occasional exceptions. A principal sceptic is Andrew Ehrenberg, previously of London Business School and now directing the market research programme at South Bank Business School, who contends that 'there are no strong brands and weak brands, only big ones and little ones.'2 It should be pointed out that Ehrenberg's extensive work has focused on market share, not profitability, so his data are not entirely pertinent. However, in most product categories, Ehrenberg shows that brands' market shares (size) are highly correlated with their repeat-buying rates (a measure of loyalty or 'equity') and thus questions whether it is possible for a brand to gain loyalty unless it becomes bigger. He doubts the need to consider loyalty or equity if market share explains all.

Further analysis (in the USA) of Ehrenberg's dictum that 'size is all' shows that exceptions do occur, such as Weeties in the breakfast cereal market, Tab in the soft drink market, and Ziploc in the plastic sandwich bag market, all of which have non-leading, and in the first two cases, very low market shares but high buyer loyalty (repeat-buying rates) which is the usual cause of superior profit. ${ }^{3}$ Fader and Schmittlein have since published data that appear to support the Ehrenberg dictum by showing that the exceptions to it are statistically rare. ${ }^{4}$ But, as these authors suggest, the main factor that obscures brand equity in favour of size is the tremendous distribution advantage that large brands command. 5 Smaller brands cannot be bought as often if their availability is limited. To equate 'better' with 'big' is, I believe, a misleading interpretation for brand management.

I believe - along with most marketers 6 that is is possible to build strong brands. The low incidence of them merely shows that it is not easy to do. I also believe that the most likely causality is: strong brand $\longrightarrow$ increased loyalty (more favourable brand attitude leading to a higher repeat-buying rate if the brand is available) $\longrightarrow$ higher relative price $\longrightarrow$ profit. The 'size' of the brand then happens to depend on the breadth of its loyalty-based appeal, ie, segment size, causally, and on distribution, spuriously.

The second question is the key, therefore: how do we build a strong brand? In the 4P's framework, if we assume that the product or service itself is pretty much a given, that price is a result rather than a cause of a strong brand, and that place or distribution also does not cause a strong brand but rather may be a result or may be due simply to company leverage, then this leaves promotion - and particularly advertising - to play the major role.

There is now considerable evidence to suggest that advertising spending or, more precisely, relative advertising spending, is positively related to a brand's equity or 
profit margin in the long run7,8,9,10 and that this effect is causal in that, mainly, advertising causes profit rather than the other way round. ${ }^{11}$ However, there is also much evidence at the more micro level that sustained brute force spend is neither the entire answer nor the most desirable answer for the manager concerned with profit.12,13 The manager would like to know, presumably, how to get more bang for fewer bucks - that is, how to achieve better advertising.

This is where our knowledge of brand management is lacking. How can the content of advertising help to build a brand? I and one of my doctoral students, Lawrence Ang, have made a tentative start to answer this question. 14 We noticed that most strong brands appear to employ a device, often a symbol, in their advertising that (a) increases the brand's recognisability or recallability within the product category 15 and (b) associates the brand with an important benefit or an appealing emotional aura. Marlboro's distinctive pack and its cowboy, McDonald's Golden Arches in the form of french fries, Jaguar's animal, and Mercury's (UK) distinctive style of advertising are cases in point. My Australian colleague, Max Sutherland, also has some ideas gleaned from his experience with the continuous tracking of advertising campaigns.16,17 But we are far short of laying out a set of principles for advertising that has brand building as its measurable goal.

I hope that my colleagues may soon have papers for The Journal of Brand Management (what better vehicle?) that address the important question of how to build a brand through advertising. It is perhaps the key question for brand management.

John R. Rossiter Editorial Board

\section{References}

(1) Moran, W. T. (1993) 'Positioning, Price and Profit: Lessons from the American Cigarette War and Elsewhere', The Journal of Brand Management, Volume 1, Number 1, pp. 147-150.

(2) Ehrenberg, A. S. C. (1993) 'If You're So Strong, Why Aren't You Bigger?', Admap, Volume 29, October, pp. 13-14.

(3) Kahn, B. E., Kalwani, M. U. and Morrison, D. G. (1988) 'Niching Versus Change-of-Pace Brands: Using Purchase Frequencies and Penetration Rates to Infer Brand Positionings', Journal of Marketing Research, Volume 25, November, pp. 384-390.

(4) Fader, P. S. and Schmittlein, D. C. (1993) 'Excess Behavioral Loyalty for High-Share Brands: Deviations from the Dirichlet Model for Repeat Purchasing', Journal of Marketing Research, Volume 30, November, pp. 478-493.

(5) Farris, P., Olver, J. and de Kluyver, G. (1989) 'The Relationship Between Distribution and Market Share', Marketing Science, Volume 8, Spring, pp. 107-127.

(6) Ambler, T. (1993) 'Are Branding and Marketing Synonymous?', The Journal of Brand Management, Volume 1, Number 1, Summer, pp. 41-48.

(7) Biel, A. (1990) 'Strong Brand, High Spend', Admap, Volume 26, November, pp. 35-40.

(8) Hume, S. (1992) 'Brand Loyalty Study', Advertising Age, 2nd March, p. 19 , reporting the research firm NPD's results.

(9) Cooil, B. and Devinney, T. (1992) 'The Return to Advertising Expenditure' Marketing Letters, Volume 3, April, pp. 137-145.

(10) Kamakura, W. A. and Russell, G. J. (1993) 'Measuring Brand Value with 
Scanner Data', International Journal of Research in Marketing, Volume 10, March, pp. 9-22.

(11) Simon, C. J. and Sullivan, M. M. (1993) 'The Measurement and Determinants of Equity: A Financial Approach', Marketing Science, Volume 12, Winter, pp. 28-52.

(12) Blair, H. (1987/1988) 'An Empirical Investigation of Advertising Wearin and Wearout', Journal of Advertising Research, Volume 27, December/January, pp. 45-50.

(13) Adams, A. J. and Blair, M. H. (1992) 'Persuasive Advertising and Sales Accountability: Past Experience and Forward Validation', Journal of Advertising Research, Volume 32, March/April, pp. 20-25.
(14) Rossiter, J. R. and Ang, L. (1992) 'Brand Equity Building for New Brands via Appropriate Advertising Symbol Selection', University of New South Wales, Australian Graduate School of Management, Working Paper, June.

(15) Rossiter, J. R. (1993) 'Brand Awareness and Acceptance: A SevenSet Classification for Managers', The Journal of Brand Management, Volume 1, Number 1, Summer pp. 33-40.

(16) Sutherland, M. (1993) 'Advertising and the Mind of the Consumer', Allen \& Unwin, Sydney.

(17) Sutherland, M. (1994) 'To Build a Brand, Use Something Old as a Link to Something New', Ad News, 8th April, pp.16-17. 